\title{
Casten Rönnow - szwedzki medyk na francuskiej prowincji w Lunéviile w latach 1737-1766
}

\author{
Casten Rönnow - a Swedish doctor in the French \\ countryside in Lunéviile, in the years 1737-1766
}

\begin{abstract}
Summary
Casten Rönnow, coming from a Swedish family with medical traditions, spent the most active years of his professional career at the court of King Stanislaus in Lunéville. He studied in Stockholm and Uppsala and continued his education abroad in Denmark, Germany, and finally in France, in Paris. He received his surgeon diploma at the University of Metz in 1730. He was a very promising surgeon in Parisian circles, with a noticeable artistic talent which he used while illustrating a treaty of a well-known military surgeon, Henri-François Le Dran. In France he joined the court of a Polish queen, Katarzyna Opalińska (the wife of King Stanislaus Leszczyński), who sent him to Konnigsberg as a trustworthy, personal doctor of King Stanisław Leszczyński. He stayed with the monarch till his death in 1766, exercising the function of "Médecin Conseiller in time du roi", but in fact, he was also the court doctor. He was called to assist in particularly difficult cases like birth fever of Mme du Châtelet or the first documented autopsy in the history of medicine performed on a dwarf, Bébé. Casten Rönnow was also a medical supervisor in the duchy of Lorraine and Bar, he participated in the establishment of the College Royale de medicine in Nancy, published scientific works. In 1744, he became a member of the Académie royale des sciences in Sweden, and after the death of King Stanislaus, when he came back from Sweden, he became the manager of this institution, opening in this way the next and the last chapter in his life.
\end{abstract}

Słowa kluczowe: medyk, Casten Rönnow, Lotaryngia, król Stanisław Leszczyński, XVIII w.

Keywords: medic, Casten Rönnow, Lorraine, king Stanislaw Leszczyński, 18th century 


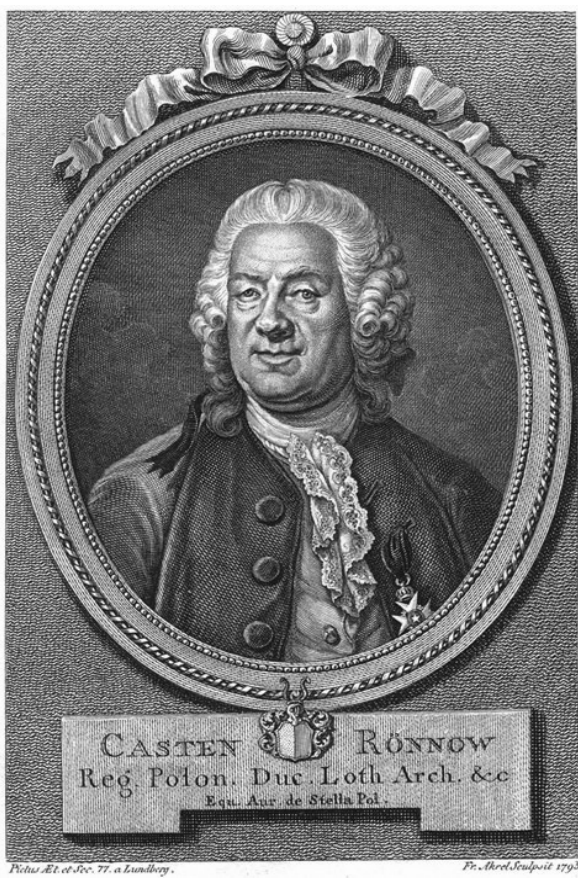

Fot. 1. Portret Casten Rönnowa, Litografia nieznanego artysty z 1793 r.

Źródło: https://www.flickr.com/photos/63794459@N07/6196670019.
Casten Rönnow lata największej aktywności zawodowej spędził na dworze króla Stanisława Leszczyńskiego $\mathrm{w}$ Lunéville. Był chirurgiem bardzo dobrze zapowiadającym się w kręgach paryskich, jednak jego losy potoczyły się inaczej. Przez ponad trzy dekady Rönnow sprawował funkcję osobistego medyka króla-azylanta, któremu w wyniku trzeciego traktatu wiedeńskiego przyznano $\mathrm{w}$ dożywotnie władanie księstwa Lotaryngii i Baru ${ }^{1}$. Należał do najbliższego grona osób w otoczeniu nowego władcy i zajmował w tym gronie uprzywilejowane miejsce. Królowi służył wiernie i skutecznie, skoro Stanisław I żył najdłużej ze wszystkich panujących władców I Rzeczypospolitej, dożywając sędziwego wieku. Nie starając się o francuskie obywatelstwo w Lotaryngii, Casten Rönnow nie był pełnoprawnym jej obywatelem. W historiografii polskiej stan badań na temat szwedzkiego medyka w służbie króla Polski, księcia Lotaryngii i Baru Stanisława Leszczyńskiego jest znikomy. Owszem, wymienia się jego nazwisko w związku z pełnioną funkcją w każdej biografii króla Stanisława. W historiografii francuskiej natomiast ukazało się dotychczas kilka artykułów naukowych ${ }^{2}$.

${ }_{1}$ Ważność drugiej elekcji króla Stanisława Leszczyńskiego w świetle trzeciego traktatu wiedeńskiego, [w:] M. Markiewicz, D. Rolnik, F. Wolański (red.), Wokót wolnych elekcji w państwie polsko-litewskim XVI-XVIII wieku. O znaczeniu idei wyboru - między prawami a obowiazkami, Katowice 2016, s. 449-463.

2 Główne prace to: A. Beau, Le docteur Casten Rönnow premier médecin du roi Stanislas, Nancy, „Le Pays Lorrain” 1972, vol. 53, no. 4; tenże, Le mort du roi stanislas 23 février du 1766, „Annales medicales de Nancy”, mars 1966, t. V, s. 205-227; G. Grignon, L. Rolland, Deux célèbres médecins du roi Stanislas : Charles Bagard et Casten Rönnow, [w:] Lunéville, fastes du Versailles Lorrain, sous la dir. Jacques Charles-Gaffiot, edité par Paris, Carpentier 2003; P. Boyé, Les derniers moments du roi Stanislas, Mémoires de la Société d'archéologie lorraine et du Musée historique lorrain, 
Casten Rönnow urodził się 15 lutego 1700 r. w Carlshamn w Szwecji, w rodzinie o długich tradycjach medycznych ${ }^{3}$. Ojca stracił $w$ roku swego urodzenia, a dwa lata później matkę. Jako sierota został przygarnięty przez wuja - Johanna Rönnowa, wojskowego lekarza z Göteborgu, który starannie nadzorował edukację bratanka, kierując go na drogę wojskowej kariery medycznej. Zatem niespełna 16-letni młodzieniec, odbywszy krótkie praktyki w szpitalach polowych, został chirurgiem wojskowym. Podczas wojny północnej leczył żołnierzy uczestniczących w walkach Szwecji z Norwegią. Studia w zakresie chirurgii podjął w $1720 \mathrm{r}$. w Sztokholmie, a następnie w Uppsali pod kierunkiem profesorów Larsa Roberga i de Leifa Rudbecka. Dzięki wstawiennictwu ostatniego $\mathrm{z}$ nich uniwersytet $\mathrm{w}$ Uppsali przyznał Rönnowowi podwójną bursę królewską ${ }^{4}$. Pragnąc uzupełnić akademicką wiedzę, młody adept sztuki chirurgicznej rozpoczął w $1728 \mathrm{r}$. swoją Grand Tour szlakiem europejskich uniwersytetów. Przebywał w Danii, w Holandii i w Niemczech, aż dotarł do Paryża, uznając go za najdogodniejsze środowisko do pogłębienia swojej wiedzy. W Paryżu, postrzeganym jako jedno $\mathrm{z}$ najważniejszych centrów duchowych ówczesnego świata, często wizytował szpitale i wydziały lekarskie na uniwersytetach, zwłaszcza te z amfiteatrami, w których przeprowadzano sekcje zwłok. Od razu został zauważony przez mistrzów, którzy rozpoznali u niego szczególny talent do rysunku i malarstwa, gdyż oglądane szczątki skrupulatnie szkicował. W stolicy Francji został uczniem jednego z najznakomitszych chirurgów epoki, za jakiego uchodził Henri-François Le Dran - główny chirurg szpitala la Charité, zwierzchnik wspólnoty paryskich chirurgów, nauczyciel anatomii w szpitalu la Charité, członek Académie Royale de Chirurgie. Profesor Le Dran zwrócił się do młodego Szweda z prośbą o wykonanie ilustracji do bardzo wyjątkowego jak na owe czasy traktatu z zakresu chirurgii: Parallèle des différentes manières de tirer la Pierre hors de la vessie [Porównywanie (zestawienie) różnych metod wyciagania kamieni z pęcherza moczowego] $]^{5}$. Rönnow rysował anatomiczne części ciała oraz narzędzia służące do przeprowadzania owych zabiegów. Praca odniosła wielki sukces i przyczyniła się

Nancy 1898, vol. 48. W sierpniu 2018 r. w pałacu w Lunéville Virginie Leroux wygłosiła prelekcję na temat: Casten Rönnow, médecin et confident de Stanislas.

3 Biographiskt lexicon öfver namnkunnige svenska män, t. 13, Uppsala 1847, s. $147-150$.

${ }^{4}$ A. Beau, Le docteur Casten..., dz. cyt., s. 161-162.

5 H.-F. Le Dran, Parallèle des différentes manières de tirer la Pierre hors de la vessie, Paris 1730. 
do ulepszenia chirurgicznych operacji brzusznych; była najpierw przetłumaczona na język niemiecki (1737), a później na angielski (1738). Pobyt Rönnowa w Paryżu trwał 7 lat. W tym czasie, w 1730 r., obronił w Reims pracę doktorską z zakresu medycyny; przyczyny wybrania przez niego uniwersytetu medycznego $\mathrm{w}$ prowincjonalnym mieście - mimo rozległych znajomości w Paryżu - nie są znane. Jest wysoce prawdopodobne, że zadecydowały o tym względy finansowe. Otwierała się przed nim droga kariery, otrzymywał propozycje dalszego rozwoju osobistego w zakresie art de guerir, tak bowiem określano nauki medyczne. Podczas wojny o polską sukcesję (1733-1735) otrzymał od księcia de Mercy propozycję dobrze płatnej posady wojskowego medyka w kompanii wojennej. $\mathrm{W}$ tym samym czasie angielski medyk Dauglas ${ }^{6}$ zaoferował mu intratną jak na owe czasy posadę w Londynie, polegającą na pomocy w praktyce lekarskiej oraz pracach przy przygotowaniu i wydaniu dzieła o anatomii. Kolejną, znacznie lepszą propozycję otrzymał od słynnego w Paryżu lekarza anatomii - Duńczyka Jacoba Benignusa Winslowa, który ofiarował utrzymującemu się samodzielnie cudzoziemcowi aż 300 liwrów za wykonanie rysunków do przygotowywanej pracy $z$ anatomii ${ }^{7}$. Propozycje te jednak przyszły nieco za późno. Wieści o zdolnym Szwedzie dotarły na dwór wersalski, do żony i córki Leszczyńskiego. Tam też zadecydowano o dalszych jego losach.

\section{Na królewskiej służbie}

Propozycję objęcia posady osobistego lekarza Stanisława Leszczyńskiego, który przebywał w owym czasie w Konigsbergu, złożyła Rönnowowi żona króla - Katarzyna Opalińska. Przynajmniej tak donosi w korespondecji z Wersalem sam zainteresowany w niecały miesiąc po śmierci swego władcy. Oto fragment z korespondencji:

«Je fus envoyé l'année 1734, par feu le Reine de Pologne, de Paris, vers Ce Pronce [Stanisław Leszczyński - M.D.] à Koenigsberg, où j'ai resté pendant quinze mois; de là j'eus l'honneur de le suivre jusqu'à Meudon et ensuite ici en Lorraine» ${ }^{8}$. (W 1734 r. zostałem wysłany przez nieżyjaca królowa Polski [Katarzynę Opalińską-M.D.], z Paryża, do księcia

${ }^{6}$ Prawdopodobnie chodzi o medyka Jamesa Douglasa (1675-1742) albo jego brata Johna. Zob. J.-M. Querald, La France litteraire, ou dictionnaire bibliographique, t. 2, Paris 1828, s. 586. Był on autorem pracy: Histoire de l'opération latérale, Paris 1734.

${ }^{7}$ A. Beau, Le docteur Casten..., dz. cyt., s. 161-162.

${ }^{8}$ Lettre de M. Rönnow, premier médecin de Sa Majesté Polonaise à M. Beaumont du 19 avril 1766; Archives Nationales Paris, K 1189 pièce 53, dalej ANP. 
[Stanisława Leszczyńskiego-M.D.] do Koenigsbergu, gdzie przebywałem piętnaście miesięcy; stamtad miałem zaszczyt towarzyszyć mu aż do Meudon, a stamtad do Lotaryngii).

$\mathrm{W}$ tej trudnej z politycznego punktu widzenia sytuacji, $\mathrm{w}$ jakiej znajdował się Leszczyński, było zasadne oddelegowanie doń zaufanego człowieka. Nie dziwi więc fakt, że żona Stanisława Leszczyńskiego - zatroskana o zdrowie i zapewne o bezpieczeństwo oddalonego o setki kilometrów męża - szukała osoby zaufanej, której lojalności byłaby pewna. Być może narodowość lekarza miała dla królewskiej małżonki jakieś szczególne znaczenie. Nie wiadomo, czym był podyktowany wybór młodego szwedzkiego lekarza. On też podjął decyzję, chociaż niewiele wiedział o politycznych uwarunkowaniach i ich konsekwencjach dla przegranego wówczas króla Polski. Dodatkowym elementem zatroskania królowej był fakt, że Stanisław donosił jej w listach o swych dolegliwościach związanych z hemoroidami, które pojawiły się już na jesieni 1733 r. Niewątpliwie czynnikiem stresującym i potęgującym bóle była ucieczka króla z Warszawy do Gdańska. W liście z Gdańska z dnia 9 grudnia (1733) skierowanym do córki Marii schorowany ojciec informował, że „słabość hemoroidalna przymusiła mię do puszczenia krwi", , w kolejnym z dnia 9 stycznia $1734 \mathrm{r}$. zapewniał córkę, że jest już zdrów i że gazety głoszą o nim fałszywe wieści ${ }^{10}$. I już w korespondencji z 15 kwietnia (1734) do córki Stanisław wspomina o lekarstwie na przeczyszczenie żołądka i wymienia po raz pierwszy nazwisko „Ronow”, z którym musi odbyć konsultacje ${ }^{11}$.

Badacz Antoine Beau podaje, że Rönnow wyjechał z Paryża na początku grudnia $1734 \mathrm{r}^{12} \mathrm{i}$ w pierwszych dniach roku następnego, czyli 1735, stawił się w Königsbergu. Jednakże w świetle korespondencji króla Stanisława zasadne jest przesunięcie daty wyjazdu z Francji o jeden rok. Młody medyk był już w kwietniu 1734 r. w Gdańsku i jego medyczne remedia były znane królowi. Dopiero później udał się wraz z Leszczyńskim do Königsbergu, gdzie król przebywał tam w „gościnie pruskiej” ${ }^{13}$. Rönnow został bardzo dobrze i serdecznie przyjęty

\footnotetext{
${ }^{9}$ List do córki, królowej Marii z dnia 9.XII.1733, Obraz Polaków i Polski w XVIII wieku, wyd. Edwarda Raczyńskiego, t. 13, Poznań 1841, s. 181.

${ }^{10}$ List do córki, królowej Marii z dnia 9.I.1734, ibidem, s. 189.

${ }^{11}$ List do córki, królowej Marii z dnia 15.IV.1734, ibidem, s. 201.

12 A. Beau, Le docteur Casten..., dz. cyt., s. 164.

${ }_{13}$ E. Szklarska, „Rząd na uchodźstwie” Emigracja królewiecka przy Stanisławie Leszczyńskim, [w:] K. Stasiewicz, S. Archemczyk (red.), Między Barokiem a Oświeceniem. Wojny i niepokoje czasów saskich, Olsztyn 2004, s. 48-56.
} 
przez nowego pana, który mocą rozporządzenia mianował go osobistym medykiem.

Od tego czasu Casten Rönnow służył wiernie królowi przez 32 lata - zarówno w chwilach spokojnych, jak i burzliwych, w radości i niepokoju, w zdrowiu i chorobie. Był przy nim wtedy, gdy król przeżywał osobiste upokorzenie, jakim było podpisanie aktu abdykacji, towarzyszył mu również podczas długiej politycznej emigracji.

W 1736 r. król Stanisław Leszczyński opuścił Prusy i na mocy trzeciego traktatu wiedeńskiego zamieszkał - w oczekiwaniu na jego realizację - we Francji na zamku w Meudon. Na początku następnego roku odbyła się oficjalna procedura przekazywania w dożywotnie władanie nowych księstw Lotaryngii i Baru. W czasie tych politycznych peregrynacji, przy boku króla Polski, a nowego księcia Lotaryngii i Baru, stał lojalny, życzliwy i skuteczny w zachowaniu dobrego zdrowia władcy medyk - Casten Rönnow.

Dlatego też wiosną $1737 \mathrm{r}$. jednym z pierwszych powołań przy tworzeniu nowego dworu ${ }^{14}$ było nadanie Rönnowowi tytułu prywatnego medycznego doradcy króla, ze szczególnym uwzględnieniem osobistego nadzorowania zdrowia Stanisława oraz administrowania działalnością medyczną w obu księstwach Lotaryngii i Baru ${ }^{15}$. Rönnow nie był jedynym lekarzem. Po przyjeździe do Lunéville poznał się z doktorem Charles'em Bagardem ${ }^{16}$ i pozostał z nim w serdecznych stosunkach. Trzecim lekarzem był Jean Christophe Kast ${ }^{17}$, pierwszy medyk królowej Katarzyny Opalińskiej, a po jej śmierci w 1747 r. - medyk i doradca królewski ${ }^{18}$. Ten lekarski korpus ponadto doglądał i instruował przysyłanych na królewski dwór młodych medyków praktykantów. Dodam w tym miejscu, że w generalnym spisie służby dworskiej

${ }^{14}$ La Cour du Roi de Pologne à Lunéville est nombreuse et brillante, „Suite de la clef, ou Journal Historique sur les matiers du temps, juillet” 1737, t. 42, Paris 1737, s. 156-157. Badacz A. Beau podaje datę 2 kwietnia 1737 r., jednakże w tym czasie Leszczyński przebywał w podróży z zamku Meudon do Lunéville i jest mało prawdopodobne, aby wtedy nadawał tytuły.

${ }^{15}$ A. Beau, Le docteur Casten..., dz. cyt., s. 164.

${ }^{16}$ Charles Bagard (1696-1772), syn medyka księcia Leopolda, lekarz miasta Nancy, założyciel Collège Royal de Médecine, znany z licznych prac badawczych nt. źródeł mineralnych i wariolizacji. Cieszył się przyjaźnią króla Stanisława. Zob. Biographie Lorraine, par Michel, Nancy 1789, s. 27.

17 Jean Christophe Kast (?-1754) - medyk królowej Katarzyny Opalińskiej, a po jej śmierci medyk króla Stanisława, doskonały lekarz, botanik, chemik, założyciel ogrodu botanicznego w Lunéville, w którym hodował bardzo rzadkie i cenne rośliny. Był opiekunem medycznym okolicznej chorej biedoty. Zob. Biographie Lorraine, par Michel, Nancy 1789, s. 276.

${ }^{18}$ http://www.aamfmn.fr/Grignon5.htm [dostęp: 17.11.2017]. 
sporządzonym w roku śmierci króla Stanisława wymienionych jest aż 10 osób z sektora służby zdrowia, czyli medyków, chirurgów i aptekarzy $^{19}$. Casten Rönnow miał uprzywilejowane miejsce wśród dworzan, był ceniony, ale również znany we francuskim prowincjonalnym środowisku lekarskim. W korespondencji z 8 kwietnia 1752 r. z kolegium medycznym w Rouen, skierowanej do organizatorów życia medycznego w księstwach Lotaryngii i Baru, wskazano na Rönnowa jako na potencjalnego dyrektora tworzonej tam medycznej instytucji ${ }^{20}$.

Casten Rönnow na dworze w Lunéville pełnił kilka funkcji: osobistego medyka króla Stanisława Leszczyńskiego i medyka dworu; organizatora życia medycznego i akademika oraz artysty malarza.

\section{Médecin Conseiller intime du Roi}

Opieka lekarska, jaką Casten Rönnow roztoczył nad Stanisławem Leszczyńskim, była skuteczna, król nie chorował bowiem zbyt często. Owszem, okazjonalnie miewał nasilone stany związane $\mathrm{z}$ hemoroidami, ale generalnie cierpiał jedynie na dolegliwości związane z niestrawnością żołądka. Jego zdrowie zaczęło się pogarszać dopiero wraz z wiekiem. Od 1754 r., czyli po przekroczeniu 76. roku życia, zaczął powoli tracić wzrok, pojawiały się kłopoty z pamięcią, z otyłością, gdyż król był znany z zamiłowania do dobrej kuchni. Dopiero w ostatnich latach życia dały się we znaki zaburzenia związane z przepływem krwi, żylaki i hemoroidy. Dolegliwości te spowodowały ograniczoną ruchliwość i ostatnie tygodnie życia król spędził na wózku inwalidzkim. W miarę upływu lat doktor Casten Rönnow był coraz bardziej potrzebny swemu panu. Przez cały okres sprawowania osobistego nadzoru medycznego aplikował królowi jedynie terapie oczyszczające, których to posłuszny medycznym zaleceniom Stanisław nie znosił. Z tego też powodu często uskarżał się w listach do córki, ta zaś namawiała go do korzystania z medykamentów Rönnowa. Tuż przed nieszczęśliwym wypadkiem przy kominku sędziwy król Stanisław był bardzo otyły, prawie niedołężny i niewidomy, cierpiał na niewydolność nerek, żylaki, miewał ataki hemoroidów. Badacz Pierre Labru$\mathrm{de}^{21}$ sugeruje, że być może cierpiał wówczas na cukrzycę. Ostatnim

${ }^{19}$ Etat de la maison du Roi Stanislas à l'epoque de sa mort en 1766. Zob. L. Lallement, Le château de la Malgrange, Paris-Nancy 1852, s. 57.

${ }^{20}$ Registres des assemblées du Collège Royale de Medicine de Nancy, A.D.M.M. 15 J. art. 7. (1751-1755), k. 7.

${ }^{21}$ P. Labrude, L'accident et la mort du roi Stanislas à Lunéville en fevrier 1766. Le traitement médicamenteux de ses brulures et les produits fournis pour son embaument, „Revue d'histoire de la pharmacie” 2007, 94e année, n³55, s. 375. 
wielkim zadaniem wynikającym z posługi medycznej oddanej dobroczynnemu władcy była opieka nad poparzonym w wyniku nieszczęśliwego wypadku królem Stanisławem. Casten Rönnow wraz z doktorem Bagardem i grupą pomagających z wielkim oddaniem lekarzy starał się ulżyć w cierpieniach króla dobroczyńcy. Na tę okoliczność sporządził raport, w którym wysyłał go do Wersalu. Od chwili poparzenia, które miało miejsce wczesnym rankiem 5 lutego 1966 r., aż do dnia zgonu 23 lutego konsylium lekarskie pod kierownictwem Rönnowa leczyło rany po poparzeniu przeróżnymi aptekarskimi miksturami ${ }^{22}$, które w jakiś sposób przynosiły doraźną ulgę w cierpieniach. Rönnow był autorem raportów opisujących te wydarzenia, które w formie sprawozdań przesyłał do Wersalu ${ }^{23}$.

Na dworze w Lunéville praktyka Rönnowa nie ograniczała się tylko do osobistego dbania o zdrowie Stanisława Leszczyńskiego. Był on odpowiedzialny również za sprawowanie opieki medycznej nad członkami dworu oraz przebywającymi tam gośćmi ${ }^{24}$. Wśród wielu dostojnych postaci goszczących w pałacowych apartamentach w Lunéville należy wymienić wieloletnią przyjaciółkę Woltera, markizę Emilie du Châtelet. Podczas pierwszego, kilkumiesięcznego pobytu u króla Stanisława w 1748 r. markiza poznała młodego poetę Saint-Lamberta, z którym nawiązała sekretny romans pod nieobecność męża, będąc dodatkowo w związku z filozofem Wolterem ${ }^{25}$. Drugi pobyt podyktowany był chęcią urodzenia dziecka właśnie w Lunéville, gdyż w wyniku romansu z przystojnym poetą zaszła $\mathrm{w}$ ciążę. Poród odbył się w nocy z 3 na 4 września 1749 r., na świat przyszła dziewczynka. Po sześciu dniach markiza dostała gorączki i jej stan stale się pogarszał. Mimo troskliwej opieki doktora Ronnowa oraz dwóch dodatkowo wezwanych lekarzy ${ }^{26}$, Emilie du Châtelet zmarła w wyniku gorączki popołogowej ${ }^{27}$.

${ }^{22}$ Szczegółowy opis użytych podczas leczenia środków podaje badacz Pierre Labrude w wyżej wymienionej pracy.

${ }^{23}$ Mort du Roi de Pologne Stanislas I, fevrier 1766, ANP, K 1189, pièce 53; Kopia dokumentu dokumentu znajduje się również pod sygnaturą 0 (1) 1044 cérémonie funèbres.

${ }^{24}$ G. Grignon, L. Rolland, Deux célèbres médecins du roi Stanislas: Charles Bagard et Casten Ronnow, [w:] Lunéville, fastes du Versailles Lorrain, sous la dir. Jacques Charles-Gaffiot, edité par Paris, Carpentier 2003, s. 211.

${ }^{25}$ P. Boyé, La cour de Lunéville en 1748 et 1749 ou Voltaire chez le roi Stanislas, Nancy 1891, s. 25-26.

${ }^{26}$ Do pomocy wezwano medyków Bagarda i Salmona, którzy podawali chorej nowe medykamenty. Niestety przyniosły one jedynie chwilową poprawę zdrowia. A. Beau, Le docteur Casten..., dz. cyt., s. 166.

${ }^{27}$ Szerzej zob. P. Boyé, La cour de Lunéville..., dz. cyt., s. 77. 
Innym bardzo ważnym zadaniem, które otrzymał doktor Ronnow, było oddelegowanie go do Metzu, kiedy uczestniczący w wojnie o austriacką sukcesję Ludwik XV ciężko zachorował. Jego zły stan zdrowia wymagał konsultacji medycznej, tak więc teść arcychrześcijańskiego króla Francji wykazał szczególną troskę, wysyłając osobistego lekarza celem wsparcia paryskich medyków.

Z polecenia króla Stanisława Casten Rönnow nadzorował sekcję zwłok $^{28}$ słynnego karła Bébé29, którą przeprowadzał nadworny chirurg Perret wraz z dwoma młodymi adeptami sztuki chirurgicznej ${ }^{30}$. Dokonano wówczas rozczłonkowania ciała na części miękkie i twarde. Pierwsze zostały złożone do specjalnie zbudowanego mauzoleum w kościele du Couvent des Minimes w Lunéville, natomiast części twarde zdeponowano - zdaniem A. Benoît - na krótko w siedzibie Akademii. Lotaryńscy medycy poza pocięciem kości na kawałki nie podjęli dalszych badań, toteż na polecenie króla Stanisława zmacerowane kawałki kości zawieziono do Paryża hrabiemu Louisowi Phélypeaux de Saint-Florentin, późniejszemu ministrowi spraw zagranicznych na dworze Ludwika XV. Hrabia skierował je do dalszych szczegółowych badań do gabinetu królewskiego prowadzonego przez Buffona, który zresztą rozpoczął nad nimi pracę ${ }^{31}$.

\section{Doradca i organizator życia medycznego w Lunéville}

Casten Rönnow odegrał znaczącą rolę w powołaniu do życia w Lotaryngii Królewskiego Kolegium Medycznego (Collège Royal de Médecine). Chociaż inicjatorem powstania był lekarz Charles Ba$\operatorname{gard}^{32}$, Rönnow wspierał go w każdej sprawie. Figurował jako jeden z dwóch członków założycieli tejże instytucji. Ci dwaj królewscy lekarze działali zgodnie, zasięgali opinii w innych podobnych francuskich ośrodkach odnośnie do regulacji prawnych, opracowali ostatecznie

${ }^{28}$ G. Grignon, L. Rolland, dz. cyt., s. 207-211.

29 Jeden z najsłynniejszych osiemnastowiecznych karłów w Europie. W maju 1764 r. Bébé zachorował, przeziębił się i miał gorączkę. Sędziwy król Stanisław, widząc, że jego zaledwie 23-letni podopieczny traci siły i umiera, wezwał jego matkę, w ramionach której po spowiedzi i ostatnim namaszczeniu wyzionął ducha 9 czerwca 1764 r. Zob. M. Durbas, Karzet Bébé z Lunéville przedmiotem badań medycznych w Paryżu w XVIII wieku, [w:] Etyka w medycynie wczoraj i dziś. Wybrane zagadnienia, Kraków 2013, s. 45.

${ }^{30}$ Jeden z nich - Nicolas Saucerotte - został później znanym lekarzem. Po sekcji zwłok karła pozostawił osobistą notatkę, która w przyszłości stała się nieocenionym źródłem historycznym. Zob. M. Durbas, dz. cyt., s. 50.

${ }^{31}$ Tamże, s. 47.

${ }^{32}$ Biographie Lorraine..., par Michel, Nancy 1789, s. 27. 
statut, który został zaakceptowany przez kanclerza i króla Stanisława. W protokołach $\mathrm{z}$ obrad królewskiego kolegium pierwsza karta informuje, że dr Rönnow - oddelegowany z Lunéville do Nancy w dniu 10 września 1751 r. - przewodniczył pierwszemu zebraniu założycielskiemu, przeprowadzając głosowanie celem wyboru komisji roboczej do dalszych prac ${ }^{33}$. W niedługim czasie kolegium medyczne rozpoczęło właściwą działalność. Instytucja ta pełniła różnorodne funkcje: była ośrodkiem wymiany myśli z zakresu nauk medycznych, korporacją zrzeszającą najlepszych lekarzy w księstwach, szkołą z lekcjami anatomii w oparciu o „sekcje zwłok” oraz placówką niosącą regularną pomoc najuboższym chorym w mieście. Casten Rönnow jako obywatel szwedzki ${ }^{34}$ nie miał praw do pełnego członkostwa w instytucji, nad której utworzeniem pracował. Został jedynie członkiem honorowym Collège Royal de Médecine $\mathrm{z}$ prawem czynnego udziału w realizacji zadań. Jego nazwisko zatem pojawia się $\mathrm{w}$ rejestrach posiedzeń medycznego towarzystwa tudzież $\mathrm{w}$ innych dokumentach ${ }^{35}$.

\section{Rönnow „malarzem" w Lunéville}

O tym, że Rönnow pełnił także funkcję malarza, dowiadujemy się ze sporządzonego po śmierci króla Stanisława dokumentu. Szwedzki medyk przesłał go do Wersalu celem otrzymania dodatkowego wynagrodzenia $^{36}$. Rönnow wyraźnie stwierdził, że na polecenie króla Stanisława malował obrazy, za które nie otrzymywał zapłaty. Ta sfera działalności królewskiego medyka na dworze w Lunéville nie jest do końca poznana. Wiadomo, że Casten Rönnow był uzdolniony artystycznie, co zauważono już w Paryżu podczas zlecanych mu prac graficznych. Tam też poznał szwedzkiego artystę pastelistę Gustava Lundberga ${ }^{37}$, który pracował nad portretem Thure Gabriela Bielkego ${ }^{38}$ oraz jego

${ }^{33}$ Registres des assemblées du Collège Royale de Medicine de Nancy (1751-1755), A.D.M.M., 15 J. art. 7, (1751-1755), k. 1.

${ }^{34} \mathrm{~W}$ literaturze przedmiotu nie ma wzmianki o tym, jakoby Casten Rönnow wyrażał chęć zmiany obywatelstwa. Należy dodać, że wiele osób z polskiego środowiska $\mathrm{w}$ Lunéville uzyskało francuskie obywatelstwo. Zob. S. Gaber, Polacy na dworze Stanisława Leszczyńskiego w Lunéville w latach 1737-1766, tłum. A.J. Zakrzewski, A. Skwara, Częstochowa 1998, s. 192.

${ }_{35}$ Registres des déliberations, assemblées, consultations, A.D.M.M., 15 J. art. 7 $15 \mathrm{~J}$ art. 12.

${ }^{36}$ A. Beau, Le docteur Casten..., dz. cyt., s. 169.

${ }_{37}$ P. Lespinasse, Les artistes suédois en France au XVIIIe siècle (1695-1804), Societé de l'histoire de l'art française, Paris, Contribution à l'histoire de l'influence française, Paris 1929.

38 Thure Gabriel Bielke (1684-1763), szwedzki oficer i dyplomata, syn Nilsa Bielkego, oficera i gubernatora Pomorza Szwedzkiego. Po bitwie pod Połtawą udał się z od- 
żony Hedwig Sack ${ }^{39}$. Casten Rönnow najprawdopodobniej pobierał u Lundberga lekcje i również przez tego artystę rodzina Leszczyńskich dowiedziała się w Wersalu o istnieniu młodego chirurga stypendysty $^{40}$. Utalentowany artystycznie szwedzki młody medyk pracował w owym czasie nad portretem profesora, u którego wcześniej pobierał nauki, rektora uniwersytetu w Uppsali - Larsa Roberga ${ }^{41}$. Jak podaje francuski badacz Gerard Voreaux, artystyczny talent Rönnowa został niezwłocznie wykorzystany przez króla Stanisława, który powierzył zdolnemu medykowi wykonanie wielu obrazów - zarówno pasteli, jak i olejnych ${ }^{42}$. Historyk sztuki Jan Ostrowski ${ }^{43}$ donosi, że pracownia artystyczna króla Stanisława znajdowała się w pałacyku Chanteheux, oddalonym o kilka kilometrów od stałej siedziby króla ${ }^{44}$. Leszczyński malował głównie techniką pastelową ${ }^{45}$. Wiadomo, że Rönnow pobierał lekcje tej techniki i doskonale się nią posługiwał, jednakże nie ustalono dotychczas, które z dzieł sygnowanych przez króla Stanisława wyszły spod ręki szwedzkiego medyka. Badacz Gerard Voreaux podaje, że w utworzonej w Lunéville efemerycznej akademii malarstwa królewski medyk udzielał lekcji rysunku niejakiemu Jeanowi Antoinemu Petersowi z Cologne ${ }^{46}$. Nadmienia ponadto, że w Sztokholmie biblioteka kolegium medycznego posiada rysunki Rönnowa i że we Francji znajduje się prawdopodobnie duża liczba jego obrazów, które nie są przezeń sygnowane ${ }^{47}$. Niestety Rönnow, jako prowincjonalny medyk na dworze w Lunéville, notabene ze szwedzkim obywatelstwem, nie był i nadal nie jest postrzegany jako postać godna zainteresowania ze strony badaczy.

działem szwedzkich żołnierzy utrzymywanych na własny koszt do Benderu, do króla Karola XII, i cały ten czas mu asystował. Następnie wysłano go z inną misją do Konstantynopola. Zob. Thure Gabriel Bielke, diplomat, general, Kavalleriofficer, Riksrad, https://sok.riksarkivet.se/Sbl/Mobil/Artikel/18183 [dostęp: 25.01.2018].

${ }^{39}$ G. Voreaux, Les Peintres lorrains du dix-huitième siècle, Paris 1998, s. 230.

${ }^{40} \mathrm{~W}$ trzeciej dekadzie XVIII w. Gustav Lundberg jako luteranin przebywał często w szwedzkiej ambasadzie w Paryżu, gdyż tylko tam znajdował się zbór luterański. Tam został pośrednio przedstawiony Stanisławowi Leszczyńskiemu, który spędził kilka lat na wygnaniu w Kristianstad. Od rodziny królewskiej, zapewne z poręki Marii Leszczyńskiej, otrzymywał zlecenia jako artysta. Zob. https://sv.wikipedia.org/wiki/ Gustaf_Lundberg [dostęp: 25.01.2018].

${ }^{41}$ Lars Roberg (1664-1742). W tej chwili obraz jest własnością uczelni.

${ }^{42}$ G. Voreaux, dz. cyt., s. 187.

43 J. Ostrowski, Stanisław Leszczyński peintre, Nancy, „Le Pays Lorrain” 1972, vol. 53 , no. 4 , s. 189.

${ }^{44}$ M. Skwarczyńska [Durbas], Ogrody króla Stanisława Leszczyńskiego w Lotaryngii w latach 1737-1766, Warszawa 2005, s. 104-108.

${ }^{45}$ J. Ostrowski, dz. cyt., s. 189.

${ }^{46}$ G. Voreaux, dz. cyt., s. 187.

${ }^{47}$ Tamże, s. 230; A. Beau, Le docteur Casten..., dz. cyt., s. 162. 
$* * *$

Kres jego prowincjonalnej służbie w Lunéville położyła zapewne śmierć króla Stanisława. Rönnow wraz z innymi opłacanymi członkami dworu znalazł się w trudnej sytuacji - dwór przestał istnieć, więc dalszy pobyt w Lunéville pozbawiony był perspektyw. Dodatkowym czynnikiem potęgującym bezzasadność pozostania we Francji był niewątpliwie fakt, że zmarły władca nie zapisał swemu oddanemu medykowi oczekiwanej przezeń, pokaźnej gratyfikacji finansowej. Dodam, że przez cały czas pełnienia służby osobistego lekarza króla Rönnow pobierał niemałą pensję, bo 4000 liwrów. W sporządzonym przez króla testamencie widnieje zapis - Rönnow otrzymał jednorazową kwotę 10000 liwrów ${ }^{48}$. Dla porównania dodam, że przy nazwisku osobistego królewskiego sekretarza Solignaca zanotowano kwotę 5000 liwrów ${ }^{49}$.

Casten Rönnow był rozczarowany i nie ukrywał swego niezadowolenia. Kiedy na polecenie księcia de Beauvais Grand Maître de la maison musiał sporządzić Raport z przebiegu leczenia króla Stanisła$w^{50}$ celem przesłania go do Paryża do intendenta finansów Francji, dołączył do niego osobisty list ${ }^{51}$. W liście zwrócił uwagę wykonawców testamentu z ramienia Wersalu na swoją trudną sytuację finansową po śmierci dobroczynnego władcy. Wyraźnie domagał się od rodziny królewskiej utrzymania renty za 32 lata służby u boku Stanisława Leszczyńskiego. Motywował to głównie tym, że za życia króla nie odniósł najmniejszej dodatkowej korzyści, poza tą, że otrzymywał stałą pensję. Zwracając się do intendenta finansów, w zawoalowanej formie powoływał się na ustne wypowiedzi dworskich urzędników, jakoby zmarły król Stanisław zamierzał utrzymać dla niego rentę w niezmienionej wysokości. Bez takiego finansowego zabezpieczenia nie mógłby utrzymywać się samodzielnie. Dodał, że był najstarszym i najwierniejszym sługą podczas ostatniego pobytu władcy w Polsce.

Vous mes permettrez aussi, Monseigneur, de profiter de cette occasion pour savoir de votre grandeur même si je puis compter sur la promesse verbale que $\mathrm{Mr}$ de la Galaiziere, ci-devant notre Chancellier, m'a faîte, de même que Alliot, que le Roi a eu la bonté de me faire conserver ma pension de quatre mille livres; c'est un effet de la clémence de Sa Majesté particulierement pour moi, qui n'ai jamais eu le mo-

\footnotetext{
${ }^{48}$ Testament du 30 janvier 1761, ADMM, Ms. SAL 57, art. 5, k. 11.

49 Tamże.

${ }^{50}$ Rapport concernant l'accident de la maladie, de la mort de S. M. P. et procèsverbal d'ouverture du corps, ANP, K. 1189 pièce no 53.

${ }^{51}$ Lettre de M. Rönnow, premier médecin de Sa Majesté Polonaise à M. de Beaumont ANP, K. 1189 pièce no 53.
} 


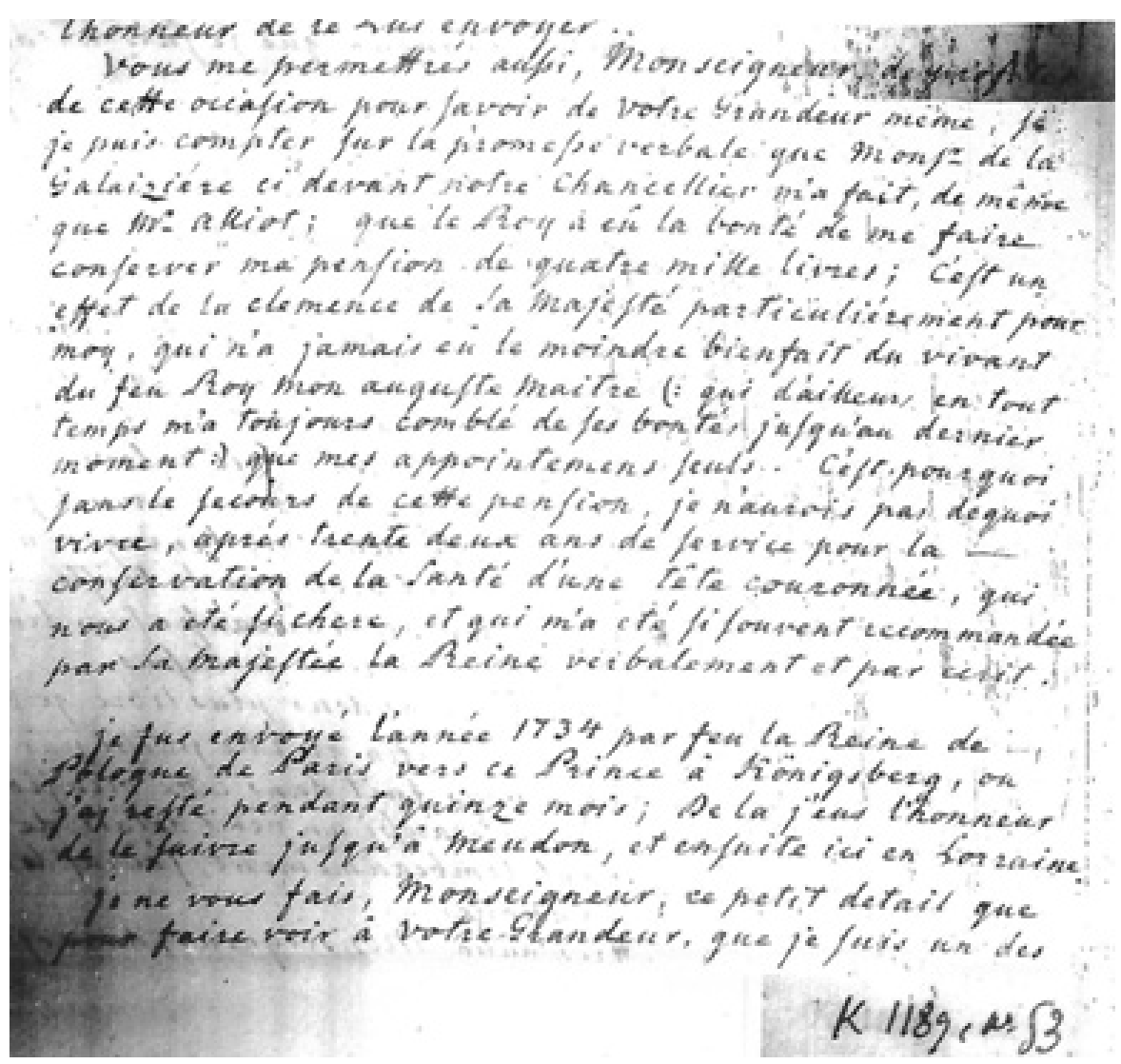

Fot. 2. Fragment listu Castena Rönnowa przesłanego do Wersalu z dnia 19 kwietnia 1766 r.

Źródło: ANP, K 1189, piece 53.

indre bienfait du vivant du feu Roy Mon Auguste Maitre [...] que mes appointements seuls. C'est pourqoi, sans le secours de cette pension, je n'aurais pas de quoi vivre, après trente-deux ans de service pour la conservation de la santé d'une tête couronnée qui nous a été si chère et qui m'a été si souvent recommandée par sa Majesté la Reine, verbalement et par écrit. [...] Je vous fais, Monseigneur, ce petit détail pour faire voir à Votre Grandeur que je suis un des plus anciens serviteurs de feu S.M. Polonaise et le seul qui a été auprès de lui pendant son dernier séjour en Pologne ${ }^{52}$. (Pozwoli mi Pan również, Wasza Ekscelencjo, skorzystać z tej okazji i poznać pańską wielkość, że mogę liczyć na słowną obietnicę, uczynioną przez pana de la Galaizière, obecnego kanclerza jak i pana Alliota, że król [Stanisław Leszczyński - M.D.] był

\footnotetext{
${ }^{52}$ Tamże.
} 
na tyle uprzejmy że przyrzekł mi zachować moją emeryturę w wysokości czterech tysięcy livrów; jest to efekt miłosierdzia Jego Królewskiej Wysokości, zwłaszcza dla mnie, nie mającego nigdy najmniejszych korzyści za życia zmarłego już króla [...] niż tylko moja pensja. Dlatego bez pomocy tej pensji nie miałbym wystarczająco dużo środków do życia; po trzydziestu dwóch latach służby dla zachowania zdrowia takiej koronowanej głowy [Stanisława Leszczyńskiego - M.D.], która była nam tak droga i tak często rekomendowana mi ustnie i pisemnie przez Jej Wysokość Królową [Katarzynę Opalińską - M.D.]. Wspominam o tym małym szczególe Wasza Ekscelencjo, aby pokazać Waszej Wysokości, że jestem jednym z najstarszych sług zmarłego polskiego króla i jedynym, który był z nim podczas ostatniego pobytu w Polsce).

Kiedy list dotarł do Wersalu, decyzją króla Ludwika XV został wydany dokument - Ogólny spis rent przyznanych dla oficerów i domowników zmarłego króla Polski Stanisława (État général des pensions [...] d'accorder aux officiers et domestiques de leu Roy de Pologne Stanislas $)^{53}$. Spis ten dowodzi, że przyznano Rönnowowi wcześniejszą rentę. Dla porównania dodam, że chirurg Charles Hilaire Perret ${ }^{54}$ otrzymał 1000 liwrów, renta Pierre'a Josepha de Solignaca wynosić miała 3000 liwrów, a ministra na dworze w Wersalu Jacques'a Hullina 6000 liwrów. Natomiast dworski poeta w osobie królewskiego lektora otrzymał tylko 300 liwrów ${ }^{55}$.

Niestety, i takie rozwiązanie nie zadowoliło szwedzkiego medyka, znajdującego się już w podeszłym jak na owe czasy wieku 66 lat. Napisał kolejne pismo ${ }^{56}$, coś w rodzaju uzasadnienia wcześniejszej prośby, w którym domagał się jednorazowej gratyfikacji finansowej. Motywował to po raz kolejny podobnymi argumentami, dodając do nich wciąż

${ }^{53}$ État général des pensions que Sa Majesté juge à propos d'accorder aux officiers et domestiques de leu Roy de Pologne Stanislas, arrêté par Sa Majesté le 13 mars 1766. ANP, E. 3265 (1), pièce 6. Zob. również: Inventaire des pensions accordées par Roi de Pologne (1765-1766), ANP, 1188 (1-91).

${ }^{54}$ Charles Hilaire Perret był głównym chirurgiem w szpitalu w Lunéville od 1757 r., a od 1763 r. pierwszym królewskim chirurgiem. Był opłacany przez tamtejszą gminę, aby zajmować się również biedotą miejską. Stanisław powierzył mu jednocześnie funkcje głównego dyrektora bezpłatnych operacji usunięcia kamieni w szpitalu Saint-Jacques w Lunéville. Było to centrum leczenia kamicy nerkowej, choroby nazywanej „maladie de pierre”, powstałe za księcia Leopolda, a utrzymywane przez króla Stanisława. Było jednym z najbardziej znanych dzięki umiejętnościom litotomistów kierowanych przez Charlesa Hilaire'a Perreta. Zob. http://www.professeurs-medecine-nancy. fr/Saidou5.htm [dostęp: 15.01.2018].

${ }^{55}$ État général des pensions que Sa Majesté juge à propos d'accorder aux officiers et domestiques de leu Roy de Pologne Stanislas, arrêté par Sa Majesté le 13 mars 1766. ANP, E. 3265 (1), piece 6.

56 Tamże, piece 27. 

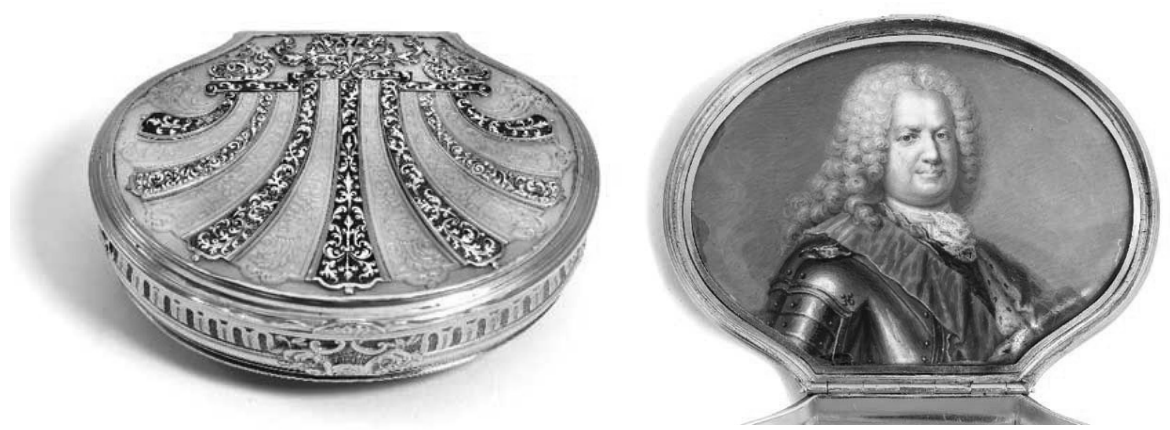

Fot. 3. Złota tabakiera z portretem króla na wewnętrznej stronie. To o niej najprawdopodobniej wspominał szwedzki medyk w liście do Wersalu

Źródło: http://www.maisondelorraine.org/nouvellesdecouvertes.php.

nowe. Twierdził, że bardzo często zastępował medyka Kasta przy chorej żonie króla Katarzynie Opalińskiej; że przez wiele lat na prośbę króla malował obrazy ${ }^{57}$ - jedne z nich były wysyłane do Paryża, a inne podlegały wyprzedaży wraz z majątkiem zmarłego władcy. Kolejnym argumentem miał być fakt, że król Stanisław obiecał podarować Rönnowowi złotą tabakierę ${ }^{58}$ ze swym wizerunkiem, ale on nigdy jej nie

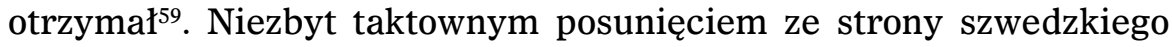
medyka było przypomnienie ministrom francuskim, że będąc oddelegowanym do Metzu do chorego króla Francji Ludwika XV, czuwał przy nim, sporządzając i przesyłając do Lunéville dzienne raporty z jego choroby. Domagał się za to pieniężnej gratyfikacji ${ }^{60}$.

Z Paryża nadeszła odpowiedź, której Rönnow zapewne się nie spodziewał. Notabene, próśb o utrzymanie renty bądź wypłacanie dodatkowych subsydiów było więcej i pod każdą z nich zapisywano notę decyzyjną, tzw. Observations, wydaną w gabinecie króla Ludwika XV.

${ }^{57}$ Jest wielce prawdopodobne, że w prywatnych kolekcjach znajdują się jeszcze obrazy wykonane anonimowo przez Castena Rönnowa. Dla przykładu podam, że w 2016 r. na aukcji w Nowym Jorku sprzedano dotychczas nieznany i anonimowy portret króla Stanisława w pasteli z XVIII w. Został on podarowany jego wnuczkom: Viktorii i Adelaidzie, które gościły u dziadka-króla w Lunéville w $1761 \mathrm{r}$. Autorstwo tego obrazu jeszcze nie jest przebadane, pracuje nad tym Neil Jeffares. Zob. http://www. maisondelorraine.org/nouvellesdecouvertes.php [dostęp: 15.01.2018].

${ }^{58}$ Autorka niniejszego tekstu przypuszcza, że chodziło o tabakiere przedstawioną na ilustracji.

59 Tabakiera wykonana ze złota, w częściach emaliowana z portretem Stanisława wewnątrz. Prawdopodobnie znajdowała się w posiadaniu króla Ludwika XVI. Zob. http://www.maisondelorraine.org/nouvellesdecouvertes.php [dostęp: 15.01.2018].

${ }^{60}$ Tamże. 


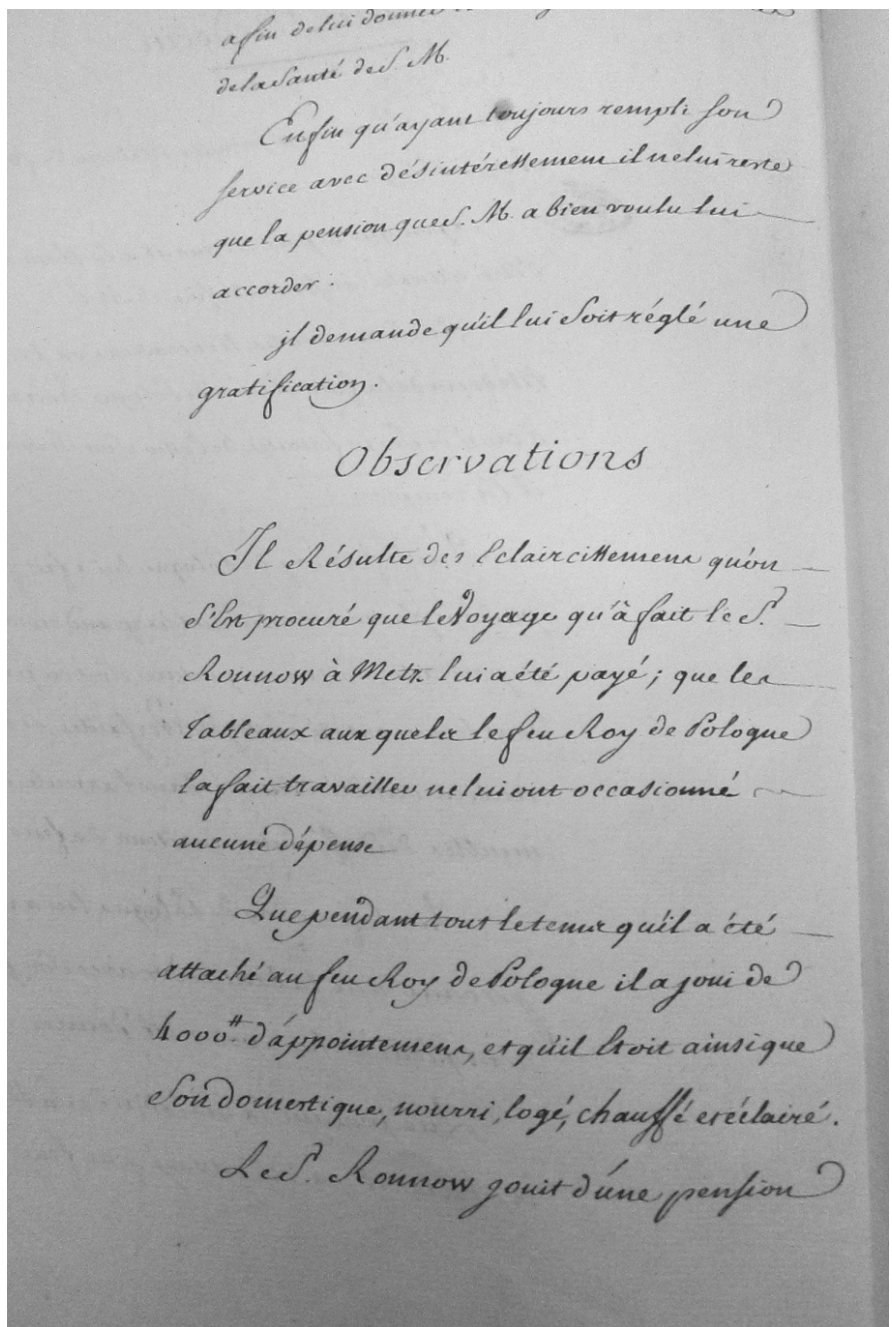

Fot. 4. Decyzja Wersalu uzasadniająca odmowę przyznania szwedzkiemu medykowi zadośćuczynienia za pełnioną służbę

Źródło: État général des pensions que Sa Majesté juge à propos d'accorder aux officiers et domestiques de leu Roy de Pologne Stanislas, arrêté par Sa Majesté le 13 mars 1766. ANP, E. 3265 (2), piece 27.

W skierowanej do medyka odpowiedzi czytamy, że z informacji, które uzyskano, wynika, iż podróż do króla Francji do Metzu została mu opłacona, że nie ponosił żadnych kosztów związanych ze zleceniem malowania obrazów; że przez cały czas, kiedy był na służbie u króla 
Stanisława, otrzymywał 4000 liwrów wynagrodzenia oraz miał zabezpieczone mieszkanie, pożywienie, ogrzewanie i oświetlenie.

Dodatkowo przez cały czas dostawał stałą pensję, a w legacji testamentowej otrzymał jednorazowo 10000 liwrów $^{61}$. W tych okolicznościach odmówiono Rönnowowi dodatkowej gratyfikacji pieniężnej. Królowa Francji Maria Leszczyńska w dowód wdzięczności zaproponowała mu pozostanie, jeśli nie w Lotaryngii, to przynajmniej w Paryżu ${ }^{62}$.

Niestety, po 30 latach pobytu w Lotaryngii, a po 32 w służbie królewskiej Casten Rönnow za namową szwedzkiego ambasadora w Paryżu, księcia Carla Scheffera, latem 1767 r. wyjechał do Szwecji. Uznał bowiem, że tam będzie miał lepsze perspektywy w jesieni życia. Czynnikiem zachęcającym był zapewne fakt, że kilka lat wcześniej król szwedzki Adolf Fryderyk nadał mu tytuł szlachecki. W 1766 r. otrzymał ponadto królewskie odznaczenie: Chevalier de l'ordre royal de l'Etoile du Nord $^{63}$. Dodatkowo wcześniejsza przynależność do Académie Royale des Sciences w Sztokholmie w charakterze członka zagranicznego otwierała przed nim drogę naukowej kariery.

Wracając do ojczyzny jako 67-letni człowiek, otworzył nowy rozdział w swojej działalności medycznej, angażując się jednocześnie w naukowe życie Szwedzkiej Akademii Nauk ${ }^{64}$. Przeżył tam jeszcze 20 lat, osiągając sędziwy wiek 87 lat. Na dworze w Lunéville jako osobisty medyk pozostawał zawsze w cieniu króla Stanisława Leszczyńskiego, jednakże wynikająca $\mathrm{z}$ tego faktu możliwość bezpośredniego kontaktu z wieloma dostojnymi reprezentantami epoki oświecenia, jak Wolter czy Monteskiusz, uczyniły z niego człowieka światłego i obytego towarzysko. $Z$ kolei swobodny kontakt $\mathrm{z}$ dworzanami należącymi do Société royale des sciences et belles-lettres oraz prowadzonymi przez nich badaniami, zwłaszcza w zakresie nauk przyrodniczych, stanowiły najlepszą rekomendację w kraju rodzinnym. Ponadto fakt wieloletnich praktyk medycznych $\mathrm{w}$ środowisku, o którym $\mathrm{w}$ połowie XVIII w. mówiła cała Europa, otwierał przed Rönnowem inne, zapewne lepsze i bardziej satysfakcjonujące go możliwości. Tak oto dopiero powrót do ojczyzny w ostatnich dekadach życia pozwolił mu rozwinąć skrzydła. Z zagranicznego członka akademii w Sztokholmie stał się jej pełnoprawnym tytularnym ogniwem oraz dwukrotnym jej dyrektorem. Brał czynny udział $\mathrm{w}$ posiedzeniach, wygłaszając oraz

\footnotetext{
${ }^{61}$ Tamże.

${ }^{62}$ A. Beau, Le docteur Casten..., dz. cyt., s. 168.

${ }_{63}$ Tamże.

${ }^{64}$ Szwedzki etap życia Castena Rönnowa i jego akademicka działalność wymagają odrębnego omówienia.
} 
publikując rozprawy naukowe ${ }^{65}$. W 1770 r. dostąpił szczególnego zaszczytu - został przyjęty na zagranicznego członka placówki naukowej, jaką była Académie Impériale des Curieux de la Nature; z kolei Société Royale de Médecine w Paryżu wybrało go również na swego zagranicznego członka. W Sztokholmie został powołany w skład kadry medycznej w Collège Royal de Médecine. Był kawalerem, przez całe życie zgromadził znaczną fortunę, którą ostatecznie przeznaczył na cele charytatywne ${ }^{66}$.

\section{Podsumowanie}

Casten Rönnow przez 32 lata pełnił funkcję pierwszego nadwornego medyka króla Stanisława, księcia Lotaryngii i Baru. Z powierzonych mu obowiązków wywiązywał się nienagannie, dbając o zachowanie dobrego stanu zdrowia nie tylko monarchy, ale także całego dworu. Należy podkreślić, że pozostawał w bliskich relacjach z tolerancyjnym monarchą, gdyż do końca pozostał wierny wyznaniu luterańskiemu. Niestety, Casten Rönnow żył w cieniu swego pracodawcy. Dopiero po śmierci władcy rozpoczął nowy etap w swym życiu. $Z$ jego wypowiedzi należy wnioskować, że lata spędzone na francuskiej prowincji u boku polskiego króla nie dały mu możliwości pełnego rozwoju ani na drodze kariery medycznej, ani artystycznej. Jego obrazy wysyłano do Paryża - jak sam podkreślał. Nie był również zadowolony z uposażenia, jakie pobierał od króla, ani też z testamentowego zapisu. Uważał wręcz, że 32-letnia służba przy boku zdetronizowanego władcy powinna dostarczyć mu więcej finansowych apanaży. Jednakże należy podkreślić, że z powierzonych mu zadań wywiązywał się z największą skrupulatnością, o czym świadczył dobry stan zdrowia sędziwego króla Stanisława I.

\section{Bibliografia}

\section{Archives Nationales Paris}

E. 3265 (1). État général des pensions que Sa Majesté juge à propos d'accorder aux officiers et domestiques de le Roy de Pologne Stanislas, arrêté par Sa Majesté le 13 mars 1766.

${ }^{65}$ C. Rönnow, Tal, von en ben eller stenaktig starr, vid hela omkretsen af uvea fastvuxen, somlyckligen blifvit med nalem nedtrigkt; hället for Kongl. vetrenskaps, Stockholm 1768; tenże, Tal, om förmånen, som hela rikets invånare tilskyndasskulle, af et stort Lazarets inrattande har i. Hufvudstadeder hallet for Kongl. vetenskops Academien, vid Praesidinedläggande, Stockholm 1774.

${ }^{66}$ A. Beau, Le docteur Casten..., dz. cyt., s. 170. 
E. 3265 (2). État général des pensions que Sa Majesté juge à propos d'accorder aux officiers et domestiques de le Roy de Pologne Stanislas (Demandes).

K 1189, pièce 53, Lettre de M. Rönnow, premier médecin de sa Majesté Polonaise à $\mathrm{M}$. de Beaumont et Rapport concernant l'accident de la maladie, de la mort de S. M. P. et procès-verbal d'ouverture du corps.

K 1188(1-91), Inventaire des pensions accordées par Roi de Pologne (1765-1766).

\section{Archives Départementales de Meurthe-et-Moselle}

Ms. SAL 57, Testament du roi Stanislas du 30 janvier 1761.

$15 \mathrm{~J}$. art. 7. Registres des assemblées du Collège Royale de Medicine de Nancy (1751-1755).

$15 \mathrm{~J}$. art. $7-15 \mathrm{~J}$ art. 9. Registres des déliberations, assemblées, consultations (1752-1774).

\section{Źródła drukowane}

Biographie Lorraine, par Michel, Nancy 1789.

Le Dran H.F., Parallèle des différentes manières de tirer la Pierre hors de la vessie, Paris 1730.

Suite de la clef, ou Journal Historique sur les matiers du temps, juillet, 1737, t. 42, Paris 1737.

Rönnow C., Tal, von en ben eller stenaktig starr, vid hela omkretsen af uvea fastvuxen, somlyckligen blifvit med nalem nedtrigkt; hället for Kongl. vetrenskaps, Stockholm 1768.

Rönnow C., Tal, om förmånen, som hela rikets invånare tilskyndasskulle, af et stort Lazarets inrattande har i. Hufvudstadeder hallet for Kongl. vetenskops Academien, vid Praesidinedläggande, Stockholm 1774.

\section{Literatura}

Beau A., Le docteur Casten Rönnow premier médecin du roi Stanislas, Nancy, „Le Pays Lorrain”, 1972, vol. 53, no. 4.

Biographiskt lexicon öfver namnkunnige svenska män, t. 13, Uppsala 1847.

Boyé P., La cour de Lunéville en 1748 et 1749 ou Voltaire chez le roi Stanislas, Nancy 1891.

Boyé P., Les derniers moments du roi Stanislas, „Mémoires de la Société d'archéologie”, lorraine et du Musée historique lorrain, Nancy 1898, vol. 48. 
Durbas M., Ważność drugiej elekcji króla Stanisława Leszczyńskiego w świetle trzeciego traktatu wiedeńskiego, [w:] M. Markiewicz, D. Rolnik, F. Wolański (red.), Wokót wolnych elekcji w państwie polsko-litewskim XVI-XVIII wieku. O znaczeniu idei wyboru między prawami a obowiązkami, Katowice 2016.

Durbas M., Karzet Bébé z Lunéville przedmiotem badań medycznych w Paryżu w XVIII wieku, [w:] Etyka w medycynie wczoraj i dziś. Wybrane zagadnienia, Kraków 2013.

Gaber S., Polacy na dworze Stanisława Leszczyńskiego w Lunéville w latach 1737-1766, tłum. A.J. Zakrzewski, A. Skwara, Częstochowa 1998.

Grignon G., Rolland L., Deux célèbres médecins du roi Stanislas : Charles Bagard et Casten Ronnow, [w:] Lunéville, fastes du Versailles Lorrain, sous la dir. Jacques Charles-Gaffiot, edité par Paris, Carpentier 2003.

http://www.professeurs-medecine-nancy.fr/Saidou5.htm.

http://www.aamfmn.fr/Grignon5.htm.

https://sok.riksarkivet.se/Sbl/Mobil/Artikel/18183.

https://sv.wikipedia.org/wiki/Gustaf_Lundberg.

Labrude P., L'accident et la mort du roi Stanislas a Lunéville en fevrier 1766. Le traitement médicamenteux de ses brulures et les produits fournis pour son embaument, „Revue d'histoire de la pharmacie” $2007,94^{\mathrm{e}}$ année, $\mathrm{n}^{\circ} 355$.

Lallement L., Le château de la Malgrange, Paris-Nancy 1852.

Lespinasse P., Les artistes suédois en France au XVIIIe siècle (16951804). Societé de l'histoire de l'art française, Paris, Contribution à 'l'histoire de l'influence française, Paris 1929.

Ostrowski J., Stanisław Leszczyński peintre, Nancy, „Le Pays Lorrain" 1972, vol. 53, no. 4,

Querald J.-M., La France litteraire, ou dictionnaire bibliographique, t. 2, Paris 1828.

Raczyński E. (wyd.), Obraz Polaków i Polski w XVIII wieku, t. 13, Poznań 1841.

Szklarska E., „Rząd na uchodźstwie” Emigracja królewiecka przy Stanisławie Leszczyńskim, [w:] K. Stasiewicz, S. Archemczyk (red.), Między Barokiem a Oświeceniem. Wojny i niepokoje czasów saskich, Olsztyn 2004.

Skwarczyńska [Durbas] M., Ogrody króla Stanisława Leszczyńskiego w Lotaryngii w latach 1737-1766, Warszawa 2005.

Voreaux G., Les Peintres lorrains du dix-huitième siècle, Paris 1998. 